Table 2 に示す. Table 2 よりつぎのことがわかつた.

（1）迅速定量法の精度 $\sigma_{\mathrm{M}}$ は $0.037 \%$ で，化学分 析の $\sigma_{\mathrm{M}}$ は $0.033^{\circ} 。$ であり, 従来の化学分析の精度と 同じである。

（2）両分析値間には有意差はないが，差のパラッキ は 0.061\%である.

（3）迅速定量法の所要時間は試料採取から分析結果 報告まで平均 13 分6 秒である。

\section{VII. 結}

標準試料を用いない分光分析法により混銑炉銑中の珪 素を迅速に定量するための発光条件, 分析線対, 唯量法, 乾板処理法を検討することによつて, 精度, 所要時間と もに満足できる迅速定量法を確立した．検討結果を各項 目ごとに要約すればつぎの通りである。

（1）溶銑中の珪素の分光分析を迅速検量法で行なう 場合, 必要な選定点はすべて自己誘導線輪の影響を受け る.

(2) SiI $2881 \cdot 58$ と. FeI $2929 \cdot 01$, FeI $28.74 \cdot 17$ の各選定点は蓄電気容量, 放電間隙, 露光時間のいずれ の影響も受けず，また交互作用も全くない，それに対し て SiI $2516 \cdot 12$ と他の鉄のスペクトル線の選定点はい ずれも自己誘導線輸以外の影暗も受け，また交互作用も ある.

（3）発光条件は自己誘導線輪 $=0.8 \mathrm{mH}$, 蓄電気容量 $=0.0033 \mu \mathrm{F}$, 放電間腺 $=2 \mathrm{~mm}$, 露光時間 $=1.5 \mathrm{mn}$ の場 合が選定点のバラッキが小さく，したがつて分析精度も すぐれている.

（4）三線法と $r$ 消却法の精度は同じであるが，三線 法の方がやや汛速的である。

（5）迅速乾板処理法を検討し，3分以内に現像から 乾燥ができるようにした。

（6）迅速分光分析法の精度 $\sigma_{M}$ 汢 $0.057 \%$ 一，化 学分析の精度と等しい. しかし化学分析值との差のバラ ッキが大きいので，さらに両分析法ともに精度の向上を はかる必要がある。

（7）迅速分光分析法による, 試料採取から分析報告 までの所要時間は 13 分 6 秒で, 転灯操業管理に直接役 立ち得ることを確認した。

\section{交献}

1）日本学術振興会編，鉄銅迅速分析法，p. 54

2) 板東, 穂坂, 江藤: 品質管理, 增刊号 6.3 (1959)

3）池上, 武井, 三上: 鉄と銓, 38 No. 11 p. 50 (1952)

4)5)7）飯島：日本鎆管技報，No.7 p. 22 (1956)

4)6）松原：日本鋼管技報，No.7 p. 33 (昭 26)
4）6）松原：日本䥀管技報，No.22 p. 36（昭 29）

8 ) 寺内：第 5 回発光分光分析研究会テキスト, p. 99 (昭31)

\section{（16）熔鉄中の岸素飽和溶解度におよ ぼす第三元素の影響}

東北大学工学部, 金属工学科

○不破 祐・藤倉正国・工博的場幸雄 Effect of Elements on the Solubility of Graphite in Liquid Iron.

Tasuku Fuwa, Masakuni Fujikura and Sachio Matoba.

\section{I. 緒言}

熔鉄中の炭素飽和溶解度におよぼ寸第三元 素の影響 についてはすでに多くの研究者により発表されてい る1〜14.そそれにも拘らずこの測定を行なつた理由は，一 つには炭素濃度の稀薄な愹鉄中における添加元素の, 炭 素の活量におよほす影響と, 同じ添加元素の, 飽和炭素 量に台よぼす影響とを比較するためである.他方多くの 人々により報告された飽和值を注意深く検討すると ${ }^{15)}$ 二 三の報告を除き，再測定の必要を感ずる．その理由は測 定值のバラッキが大き過ぎることと, 測定者によつて相 当測定結果が異なることである. 測定值のバラッキは炭 素定量試料採取法に原因し，测定者による差違は同梯試 料採取法と温度測定に原因があると考えられる。

添加元素としては $\mathrm{Ni}, \mathrm{Co}, \mathrm{Sn}, \mathrm{W}, \mathrm{Mo}, \mathrm{Cu}$ につきそ れぞれその影響について測定した。

\section{II. 実験装置および方法}

熔解炉は的場，万谷両氏 ${ }^{13)}$ の用いた反応管をそのまま 用い，電解鉄にあらかじめ合金元素を添加して黑鉛坩佩 (在分 0.08 以下) 中でアルゴン気流中て狺解し, 温度を $1450^{\circ} \mathrm{C}$ に一定に保ち，大部分が 2 時闃保持された。分 析試料は内径 $3 \mathrm{~mm}$ の石英管に吸引儿た。飽和值は子 備実験の結果 70〜90 mn で得られた。 アルゴンは 450 ○比熱した切削した金属マグネシウムを通して酸素

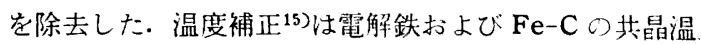
度を利用して行なつた。

石英管に吸引された試料は表面をエメリ一紙で磨いて 適当な長さに切断し，その円筒型の試片を粉砕して，粉 砕物のすべてを一回の炭素定量試料に供した。この粉确 したものを全部一回の試料にすることにより，炭素定量 值のバラッキを防ぐことができた.なお金のこで切断で 
きないものは吸引試料を万力に保持し, 適当な長さに衝 撃破片をつくり，破片全部を前述の円筒型試料同様に粉 砕して定量した。

炭素は燃焼重量法により， Ni， Co, W, Mo を含え だ試料には助燃剤 $\left(\mathrm{Pb}_{3} \mathrm{O}_{4}\right)$ を用いた。添加元素は化学 分析（標準法）により定量した.

\section{III. 実 験 結 果}

$1450^{\circ} \mathrm{C}$ における熔鉄中の飽和炭素量は $5 \cdot 14 \%\left(\mathrm{~N}_{\mathrm{C}}=\right.$ 0.2012）と得られた.

Fe-C-Ni 系の結果は Table 1 に示多. Turkdogan らの $1550^{\circ} \mathrm{C}$ に打引る測定值同様 $\mathrm{N}_{\mathrm{Ni}}=0.75$ 付近に飽 和炭素量が最小值を示す。これは $\mathrm{Fe}-\mathrm{Ni}$ 二元系は全域 にわたり理想溶液と考えられていることに再検討を要す る.

Table 1. Solubility of carbon in iron-nickel alloys at $1450^{\circ} \mathrm{C}$.

\begin{tabular}{|c|c|c|c|c|}
\hline \multirow{2}{*}{$\begin{array}{l}\text { Heat } \\
\text { No. }\end{array}$} & \multicolumn{2}{|c|}{ Weight percent } & \multicolumn{2}{|c|}{ Mole fraction } \\
\hline & Nickel & Carbon & Nickel & Carbon \\
\hline$F-58$ & $20 \cdot 00$ & $4 \cdot 08$ & $0 \cdot 16_{7}$ & $0.16_{7}$ \\
\hline F K -38 & $30 \cdot 07$ & $3 \cdot 55$ & $0 \cdot 25_{6}$ & $0 \cdot 14_{8}$ \\
\hline F -40 & $49 \cdot 58$ & $2 \cdot 68$ & $0 \cdot 439$ & $0 \cdot 11_{6}$ \\
\hline$F-46$ & $70 \cdot 01$ & $1 \cdot 99$ & $0 \cdot 64_{1}$ & $0.08_{B}$ \\
\hline F -41 & $74 \cdot 80$ & $1 \cdot 72$ & $0.69_{4}$ & $0.07_{8}$ \\
\hline$F-45$ & 80.01 & $1 \cdot 58$ & 0.747 & $0.07_{2}$ \\
\hline F -59 & $85 \cdot 00$ & $1 \cdot 66$ & $0 \cdot 79_{3}$ & $0.07_{6}$ \\
\hline F K -54 & $\therefore 0 \cdot 00$ & $1 \cdot 80$ & $0 \cdot 83_{8}$ & $0 \cdot 08_{2}$ \\
\hline F K -55 & $09 \cdot 00$ & $2 \cdot 00$ & $0 \cdot 9 \mathrm{C}_{9}$ & $0.09_{1}$ \\
\hline
\end{tabular}

Fe-C-Co 采う結果は Table 2 に示す.

Table 2. Solubility of carbon in iron-cobalt alloys at $1450^{\circ} \mathrm{C}$

\begin{tabular}{c|c|c|c|c}
\hline \multirow{2}{*}{$\begin{array}{c}\text { Heat } \\
\text { No. }\end{array}$} & \multicolumn{2}{|c|}{ Weight } & percent & \multicolumn{2}{c}{ Mole fraction } \\
\cline { 2 - 5 } \cline { 3 - 5 } & Cobalt & Carbon & Cobalt & Carbon \\
\hline F- 43 & $10 \cdot 03$ & $4 \cdot 70$ & $0 \cdot 08_{1}$ & $0 \cdot 18_{9}$ \\
F-110 & $30 \cdot 01$ & $4 \cdot 15$ & $0 \cdot 25_{0}$ & $0 \cdot 17_{0}$ \\
F-42 & $49 \cdot 98$ & $3 \cdot 77$ & $0 \cdot 42_{5}$ & $0 \cdot 15_{8}$ \\
F-111 & $60 \cdot 00$ & $3 \cdot 74$ & $0 \cdot 51_{5}$ & $0 \cdot 15_{7}$ \\
F-44 & $75 \cdot 00$ & $3 \cdot 47$ & $0 \cdot 65_{9}$ & $0 \cdot 15_{0}$ \\
F-109 & $95 \cdot 09$ & $3 \cdot 33$ & $0 \cdot 74_{8}$ & $0 \cdot 14_{4}$ \\
F-88 & $96 \cdot 71$ & $3 \cdot 29$ & $0 \cdot 85_{7}$ & $0 \cdot 14_{3}$ \\
\hline
\end{tabular}

Fe-C-W 系, Fe-C-Mo 系の結果はそれぞれ Table 3〜 亿示す. Mo は飽和炭素量を増加するが W 添加 の影響はほとえど認められない。

$\mathrm{Fe}-\mathrm{C}-\mathrm{Cu}$ 系の結果は Table 5 に, Fe-C-Sn系の結 果沬 Table、6 に示す.

得られた結果を $\log N c-N_{j}$ につき直角座標にとり，
Table 3. Solubility of carbon in iron-tungsten alloys at $1450^{\circ} \mathrm{C}$.

\begin{tabular}{c|c|c|c|c}
\hline \hline \multirow{2}{*}{$\begin{array}{l}\text { Heat } \\
\text { No. }\end{array}$} & \multicolumn{2}{|c|}{ Weight percent } & \multicolumn{2}{c}{ Mole fraction } \\
\cline { 2 - 5 } & Tungsten & Carbon & Tungsten & Carbon \\
\hline F-66 & $6 \cdot 07$ & $5 \cdot 01$ & $0 \cdot 01_{6}$ & $0 \cdot 20_{4}$ \\
F-67 & $10 \cdot 12$ & $4 \cdot 78$ & $0 \cdot 02_{8}$ & $0 \cdot 20_{1}$ \\
F-68 & $14 \cdot 48$ & $4 \cdot 62$ & $0 \cdot 04_{1}$ & $0 \cdot 20_{1}$ \\
\hline
\end{tabular}

Table 4. Solubility of carbon in ironmolybdenum alloys at $1450^{\circ} \mathrm{C}$

\begin{tabular}{|c|c|c|c|c|}
\hline \multirow{2}{*}{$\begin{array}{l}\text { Heat } \\
\text { No. }\end{array}$} & \multicolumn{2}{|c|}{ Weight percent } & \multicolumn{2}{|c|}{ Mole fraction } \\
\hline & $\begin{array}{l}\text { Moly- } \\
\text { bdenum }\end{array}$ & Carbon & $\begin{array}{l}\text { Moly- } \\
\text { bdenum }\end{array}$ & Carbon \\
\hline $\begin{array}{l}F-61 \\
F-64 \\
F-63 \\
F-65 \\
F-100 \\
F-85\end{array}$ & $\begin{array}{r}8 \cdot 72 \\
13 \cdot 85 \\
16 \cdot 60 \\
21 \cdot 52 \\
35 \cdot 31 \\
45 \cdot 04\end{array}$ & $\begin{array}{l}5 \cdot 16 \\
5 \cdot 16 \\
5 \cdot 17 \\
5 \cdot 21 \\
5 \cdot 33 \\
5 \cdot 76\end{array}$ & $\begin{array}{l}0 \cdot 04_{4} \\
0 \cdot 07_{2} \\
0 \cdot 08_{6} \\
0 \cdot 13_{8} \\
0 \cdot 19_{6} \\
0 \cdot 25_{6}\end{array}$ & $\begin{array}{l}0 \cdot 20_{8} \\
0 \cdot 21_{2} \\
0 \cdot 21_{5} \\
0 \cdot 22_{0} \\
0 \cdot 23_{7} \\
0 \cdot 26_{1}\end{array}$ \\
\hline
\end{tabular}

Table 5. Solubility of carbon in iron-copper alloys at $1450^{\circ} \mathrm{C}$.

\begin{tabular}{c|c|c|c|c}
\hline \hline \multirow{2}{*}{$\begin{array}{c}\text { Heat } \\
\text { No. }\end{array}$} & \multicolumn{2}{|c|}{ Weight percent } & \multicolumn{2}{c}{ Mole fraction } \\
\cline { 2 - 5 } & Copper & Carbon & Copper & Carbon \\
\hline F K-107 & $1 \cdot 27$ & $5 \cdot 13$ & $0 \cdot 00_{9}$ & $0 \cdot 20_{\mathbf{1}}$ \\
F K-102 & $2 \cdot 27$ & $5 \cdot 00$ & $0 \cdot 01_{7}$ & $0 \cdot 19_{7}$ \\
F K-78 & $3 \cdot 29$ & $4 \cdot 77$ & $0 \cdot 02_{5}$ & $0 \cdot 18_{9}$ \\
F K-103 & $4 \cdot 25$ & $4 \cdot 73$ & $0 \cdot 03_{2}$ & $0 \cdot 18_{\mathbf{8}}$ \\
F K-105 & $5 \cdot 22$ & $1 \cdot 57$ & $0 \cdot 03_{9}$ & $0 \cdot 18_{8}$ \\
\hline
\end{tabular}

Table 6. Solubility of carbon in iron-tin alloys at $1450^{\circ} \mathrm{C}$

\begin{tabular}{|c|c|c|c|c|}
\hline \multirow{2}{*}{$\begin{array}{l}\text { Heat } \\
\text { No. }\end{array}$} & \multicolumn{2}{|c|}{ Weight percent } & \multicolumn{2}{|c|}{ Mole fraction } \\
\hline & Tin & Carbon & Tin & Carbon \\
\hline $\begin{array}{l}F-31 \\
F-51 \\
F-35 \\
F-53\end{array}$ & $\begin{array}{r}6 \cdot 30 \\
23 \cdot 42 \\
37 \cdot 48 \\
70 \cdot 53\end{array}$ & $\begin{array}{l}4 \cdot 05 \\
1 \cdot 37 \\
0 \cdot 64 \\
0 \cdot 05_{3}\end{array}$ & $\begin{array}{l}0.027 \\
0 \cdot 11_{9} \\
0 \cdot 21_{4} \\
0.528\end{array}$ & $\begin{array}{l}0.168 \\
0.06 \\
0.036 \\
0.00\end{array}$ \\
\hline
\end{tabular}

Slope $\left.^{15}\right)=\left(\delta \log N_{c} / \delta N_{j}\right) a_{c}$ をとり， 従来の各元素说 ついての値と比較すると Table 7 のようになる.

$$
\text { V. 結 }
$$

熔鉄中の飽和炭素量におよぼす $\mathrm{Ni}, \mathrm{Co}, \mathrm{W}, \mathrm{Cu}, \mathrm{Sn} の$ 影響を $1450^{\circ} \mathrm{C}$ で測定し，つぎのうな值を得た。

$$
\begin{aligned}
& \left(\frac{\partial \log N_{c}}{\partial N_{j}}\right)_{a_{c}} \varepsilon_{c}^{(j)}=\left(\frac{\delta \ln f_{c}}{\delta N_{j}}\right)_{N_{c}} \\
& \mathrm{Ni}-0.54+3.5
\end{aligned}
$$




$\begin{array}{lcc}\text { Co } & -0.26 & +1.7 \\ \text { W } & 0 & 0 \\ \text { Mo } & 0.34 & -2.2 \\ \text { Cu } & -1.0 & +6.4 \\ \text { Sn } & -2.82 & +18.1\end{array}$

Table 7. Effects of several elements on the solubility of graphite in liquid iron.

\begin{tabular}{|c|c|c|c|}
\hline $\begin{array}{l}\text { Alloying } \\
\text { element }\end{array}$ & $\begin{array}{c}\text { Temp } \\
{ }^{\circ} \mathrm{C}\end{array}$ & $\left(\frac{\delta \log \mathrm{Nc}}{\delta \mathrm{Nj}}\right) a$ & References \\
\hline \multirow[t]{2}{*}{ Nickel } & 1490 & -0.40 & 2 \\
\hline & 1550 & $-0 \cdot 42$ & 12 \\
\hline \multirow{2}{*}{ Cobalt } & 1450 & -0.54 & This work \\
\hline & $\begin{array}{l}1550 \\
1450\end{array}$ & $\begin{array}{l}-0.22 \\
-0.26\end{array}$ & This work \\
\hline \multirow[t]{2}{*}{ Tungsten } & 1550 & $+0 \cdot 20$ & 16 \\
\hline & 1450 & 0 & This work \\
\hline \multirow{2}{*}{ Molybdenum } & 1550 & $+0 \cdot 47$ & 16 \\
\hline & 1450 & $+0 \cdot 34$ & This work \\
\hline \multirow[t]{2}{*}{ Copper } & $\begin{array}{l}1600 \\
1550\end{array}$ & $\begin{array}{l}-1 \cdot 80 \\
-0.07\end{array}$ & $\begin{array}{r}8 \\
16\end{array}$ \\
\hline & 1450 & $-1 \cdot 00$ & This work \\
\hline \multirow[t]{2}{*}{ Tin } & 1550 & $-42 \cdot 0$ & 14 \\
\hline & 1450 & $-2 \cdot 8_{2}$ & This work \\
\hline \multirow{5}{*}{$\begin{array}{l}\text { Aluminum } \\
\text { Chromium } \\
\text { Niobium } \\
\text { Manganese }\end{array}$} & 1600 & $-1 \cdot 17$ & 7 \\
\hline & 1620 & +0.42 & 13 \\
\hline & 1620 & $+1 \cdot 80$ & 15 \\
\hline & 1490 & +0.22 & 6 \\
\hline & $\begin{array}{l}1500 \\
1490\end{array}$ & & $3,11,13$ \\
\hline \multirow{2}{*}{ Phosphorus } & $\begin{array}{l}1490 \\
1600\end{array}$ & $-2 \cdot 0$ & $\begin{array}{r}11 \\
2\end{array}$ \\
\hline & 1450 & $-2 \cdot 6$ & $\begin{array}{l}2 \\
9\end{array}$ \\
\hline \multirow{4}{*}{$\begin{array}{l}\text { Silicon } \\
\text { Sulphur }\end{array}$} & 1600 & $-1 \cdot 75$ & 6,13 \\
\hline & $1250 \sim 1500$ & $-1 \cdot 75$ & 12 \\
\hline & 1500 & $-7 \cdot 4$ & 10 \\
\hline & 1250 & $-11 \cdot 0$ & 9 \\
\hline \multirow{2}{*}{$\begin{array}{l}\text { Vanadium } \\
\text { Arsenic }\end{array}$} & 1560 & $+0 \cdot 9.5$ & 15 \\
\hline & 1550 & $-4 \cdot 95$ & 14 \\
\hline
\end{tabular}

Table 7 に示すように，従来の研究と比較し，かなり 差違があることは，さらに今後の研究にまつとともに， 従来考えられていたように温度の影響は無視できないこ とを暗示しているように思われる。

\section{交献}

1) R. Ruer \& J. Biren: Zeit. Anorg. Allge. Chem., 113 (1920) p.98 112

2) K. Schichtel \& E. Piwowarsky: Arch. Eisenhüttw., 3 (1929) p.139 147

3）三本木，大谷: 選研㑰報， 11 (1956）2，p.1

4) M. Ohtani: Sci. Repts Res. Inst. Tohoku Univ., A7 (1955) p. 487 50!

5）大谷正康：鉄と鋼，43 (1957) p.112

6) J. Chipman et al: J. Am. Soc. Metals, 44 (1952) p. $1215 \sim 1230$

7) J. Chipman \& T. P. Floridis: Acta Metall., 3 (1954) p. $456 \sim 459$

8) J. Chipman \& P. Koros: J. of Metals, 8 (1956) p. $1102 \sim 1104$
9) N. A. Vatolin \& O. A. Esin: J. General. Chem. of u. S.S. R., 26 (1956) p. 1543

10) J. A. Kitchner, J.O.M. Bockris \& D. A. Spatt: Trans. Faraday Soc. 48 (1952) p. $608 \sim 617$

11) E. T. Turkdogan \& L. E. Leake: J.I.S.I., 179 (1955) p. 39 43, p. 43〜 45, p. $155 \sim 159$, p. $269 \sim 271$

12) E. T. Turkdogan, R. A. Hancock \& S. I. Herlitz: J. I. S. I. 182 (1956) 274 277, 183 (1956) 69

13）万谷志郎，的場幸雄：鉄と鎙，44（1958） p. 6, 学振 19 委 4361 (1956)

14）沢村宏, 盛利且, 小林, 宮下: 学振 19 委一5105 (1958)

15) J. Chipman, 不破祐: 学振 19 委一4900 (1958) Trans. AIME, 215 (1959) p. 708 716

16）盛利貞, 明田莞, 尾野均, 杉田宏: 学振 19 委一 5569 (1959)

鉄と銅，45（1959） p. 929〜930

（17）熔鉄中の炭素と酸素の活量につ いて

東北大学工学部, 金属工学科

工博O万谷 志郎. 工博 的場 幸雄

Activity of Carbon and Oxygen in

Molten Iron.

Shiro Ban-ya and Sachio Matoba.

\section{I. 緒}

\section{言}

焀鉄中の炭素と酸素の反応はつぎの3 式で示される。

$$
\begin{aligned}
& \underline{\mathrm{C}}+\mathrm{CO}_{2}=2 \mathrm{CO} \\
& \underline{\mathrm{O}}+\mathrm{CO}=\mathrm{CO}_{2} \\
& \underline{\mathrm{C}}+\underline{\mathrm{O}}=\mathrm{CO}
\end{aligned}
$$

本系の平衡測定は鉄鋼製鍊の基礎反応で古くより多く の研究が行なわれてきた。しかしそれらの報告における 炭素搌度の測定範囲は比較的狭く，また繂密な化学平衡 諭的立場より全炭素濃度につき測定したものとしては未 だ充分なものがない状態である.

本報告は広い炭素濃度範囲における熔鉄中の炭素，酸 素と $\mathrm{CO}-\mathrm{CO}_{2}$ 混合ガス間の平衡関係を測定してその活 量を求めたものである. 実験上最も困難な点は $\mathrm{CO}_{2}$ ガ ス混合比がきわめて少なく，その混和，検定の難しいこ こ, CO ガスの炉内での分解 (Carbon Deposition)に よるガス混合比の変化，および炉内の熱的不均一による 実験誤差，坩堝の耐火物の問題，平衡到達時間の長いこ となどで，これらの点を充分考虑して $1460 〜 1760^{\circ} \mathrm{C}$ ， 
$\mathrm{P}^{2} \mathrm{co} / \mathrm{P}_{\mathrm{CO}_{2}}=50 \sim 3000$, 炭素浱度 0.1 2.5\% C の範囲 の測定を行なつた.

\section{II. 実 験 方 法}

1. 実験装置

$\mathrm{CO}_{2}$ ガスはボンベガスを用い，CO ガスは熱した硫 酸に蟻酸を滴下して作り充分洗涤して使用した. $\mathrm{CO}$ ガ スは常に $200 \mathrm{cc} / \mathrm{mn}$ の制合で流し，これに $\mathrm{CO}_{2}$ ガスを 微量毛管流量計にて常に一定量 (4 0.05cc/mn) 混入 せしめて反応管内に送り込む. 流量計前後の圧力関係を

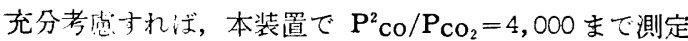
可能であつた. $\mathrm{CO}-\mathrm{CO}_{2}$ 混合ガス中の $\mathrm{CO}_{2}$ ガス量の検 定は，液体空気を使用する減圧容量法により行なつた。

熔解用炉は $20 \mathrm{kVA}$ の高周波炉を使用し，温度測定 は光高温計により行なつた。

反応管は内径 $38 \mathrm{~mm} \phi$ の不透明石英で，坩堝は Mo 板円筒または黒鉛保讙坩堝に入れて，ポーセレン製支持 台の上に乗せる．炉内の発熱部分の温度勾配には十分注 意し, carbon deposition による副次反応をおさえる ようにした：このことは予備実験で十分検討を行つた。

2. 坩堝および試料

試料は電解鉄を真空熔解した純鉄, および実験室にて 熔製した白銑を適度に配合し，1熔解につき 40〜 45 g を使用した。坩堝は実験室にて作製した $\mathrm{MgO}$ 咁堝およ び $\mathrm{CaO}$ 坩堝をもちいた. $\mathrm{MgO}$ 坩堝は高温度でかなり の oxygen potential を持ち, 高炭素濃度範囲では使 用できないことが明らかになつた。

3 . 実験操作

各試料は, $\mathrm{CO}-\mathrm{CO}_{2}$ 混合ガス䨌囲気にて一定条件で 塎解後, 高周波の電流を切り, 下部にさげ急冷する. 0.3\% C一以下の炭素濃度では, 電流を切る 10～1.5秒前に 0.5\% 程度の A1 を加えて試料を鎮静した. 熔解時間は 10時間を単位として打切り, 熔解前後の炭素濃度の变化 量より平衡值を求めた.

急冷した試料は，これを中心より 4 等分して，分析試 料を採取した，炭素分析は乾式燃焼法を，酸素分析は真 空熔融法（4〜8g 試料）を採用した。

\section{III. 実駼結果および考察}

以上の方法により $1460^{\circ}, 1560^{\circ}, 1660^{\circ}, 1760^{\circ} \mathrm{C}$ の 各温度において $\mathrm{P}^{2} \mathrm{co} / \mathrm{P}_{\mathrm{CO} 2}=50 \sim 3000$, 炭素濃度 $0.1 \sim$ $2 \cdot 5 \%$ C の範囲につき測定を行なつた.

1. $\frac{\mathrm{C}}{K_{1}}+\mathrm{CO}_{2}=2 \mathrm{CO}$

$$
\log a_{\mathrm{C}}=\log N_{\mathrm{C}}+\log f_{\mathrm{C}}^{(\mathrm{C})}+\log f_{\mathrm{C}}^{(\mathrm{O})}
$$

ただし $N_{\mathrm{c}}$ は熔鉄中における炭素の mole fraction,
$f_{\mathrm{C}}^{(\mathrm{C})}$ は炭素の活量係数, $f_{\mathrm{C}}^{(\mathrm{O})}$ は炭素の活量係数におよ ぼす酸素の影響.

$\mathrm{CO}-\mathrm{CO}_{2}$ 混合ガスと熔鉄中の炭素濃度との関係は (1) 式で示されこの見かけの平衡恒数 $K_{1}{ }^{\prime}\left(=\mathrm{P}^{2} \mathrm{co} / \mathrm{P}_{\mathrm{Co}_{2}} \cdot N_{\mathrm{C}}\right)$ は炭素浱度とともに増加する傾向を示す。すなわちとの 場合熔鉄中の炭素の活量係数を考虑すべきことは明らか であり，今活量の基準を無限稀薄溶液にとれば，炭素の 活量 $a_{\mathrm{c}}$ : (1') 式で示され，炭素濃度の高い範团では $\log f_{\mathrm{C}}^{(0)}$ を無視し得るものとして測定結果を総合して下 記の関係が得られた。

$$
\begin{aligned}
& \log K_{1}\left(=\frac{\mathrm{P}^{2} \mathrm{CO}}{\mathrm{P}_{\mathrm{CO}_{2}} a_{\mathrm{C}}}\right)=-\frac{7,560}{\mathrm{~T}}+6 \cdot 76 \cdots \\
& \Delta \mathrm{F}_{1}{ }^{0}=34,600-30 \cdot 9 \mathrm{~T} \\
& \text { ただし } \underline{\mathrm{C}} \% \rightarrow 0 \quad a_{\mathrm{C}} / \underline{\mathrm{C}} \% \rightarrow 1 \\
& \frac{\partial \log f_{\mathrm{C}}^{(\mathrm{C})}}{\partial N_{\mathrm{C}}}=6 \cdot 40 \cdots \cdots \cdots \cdots<0 \cdot 09 N_{\mathrm{C}} \cdots \cdots \\
& e_{\mathrm{C}}^{(\mathrm{C})}=\frac{\partial \log f_{\mathrm{C}}^{(\mathrm{C})}}{\partial \underline{\mathrm{C}} \%}=0 \cdot 298 \cdots(\text { very dil) } \cdots
\end{aligned}
$$

これらの值と，炭素飽和における $\mathrm{Fe}-\underline{\mathrm{C}}-\underline{\mathrm{O}}$ 系平每 測定の著者らの值》から熔融鉄炭素合金の全系について 炭素の活量を求めた. $1560^{\circ} \mathrm{C}$ における值を Table 1 K 示す. Table 1 中には活量の基準を無限稀薄溶液におい た時の炭素の活量および活量係数 $a_{\mathrm{c}}, f_{\mathrm{C}}$, 固体炭素に 基準をおいた時の活量および活量係数 $a_{\mathrm{c}}, \gamma_{\mathrm{c}}$, 炭素の 溶解にともなう溶解熱, entropy，および Gibbs-Duhem の式より求めた鉄の活量を併記した.

2. $\underline{\mathrm{O}}+\mathrm{CO}=\mathrm{CO}_{2}$

$$
\begin{aligned}
& K_{2}=\mathrm{P}_{\mathrm{CO}_{2}} / \mathrm{P}_{\mathrm{CO}} \cdot a_{\mathrm{O}} \\
& \log a_{\mathrm{O}}=\log \underline{\mathrm{O}} \%+\log f_{\mathrm{O}}^{(\mathrm{C})}+\log f_{\mathrm{O}}^{(\mathrm{O})}
\end{aligned}
$$

（2）式における見掛け上の平衡恒数 $K_{2}{ }^{\prime}\left(=\mathrm{P}_{\mathrm{CO}_{2}} / \mathrm{P}_{\mathrm{co}}\right.$. 0％）は実験結果によると炭素濃度の増加ととも次第 に減少し, 酸素の活量係数は炭素によりいちじるしく低 下することを示している．今活量の基準を無限稀薄溶液 に取れば, 酸素の活量は $\left(2^{\prime}\right)$ 式で示され，高炭素浱度 では $\log f_{0}^{(0)}$ を無視し得るとすれば測定結果よりつき の式を得る.

$$
\begin{aligned}
& \log K_{2}\left(=\frac{\mathrm{P}_{\mathrm{CO}_{2}}}{\mathrm{P}_{\mathrm{CO}} \cdot a_{\mathrm{O}}}\right)=\frac{8,720}{\mathrm{~T}}-4 \cdot 76 \cdots \cdots \\
& \Delta \mathrm{F}_{2}{ }^{0}=-39,900+21 \cdot 8 \mathrm{~T} \\
& \frac{\partial \log f_{\mathrm{O}}^{(\mathrm{C})}}{\partial N_{\mathrm{C}}}=-9 \cdot 05 \cdots \cdots \cdots \cdots<0 \cdot 09 N_{\mathrm{C}}
\end{aligned}
$$


Table 1. Activities of carbon and iron.

\begin{tabular}{|c|c|c|c|c|c|}
\hline & & ${ }_{1560^{\circ} \mathrm{C}}^{\log \gamma_{c}^{(c)}}$ at & $\begin{array}{c}\log f_{\mathrm{c}^{(c)}} \text { at } \\
\text { any temp. }\end{array}$ & $\begin{array}{c}\text { at } \\
1560^{\circ} \mathrm{C}\end{array}$ & $\begin{array}{c}\text { at } \\
1560^{\circ} \mathrm{C}\end{array}$ \\
\hline & \multicolumn{5}{|c|}{ Standard states } \\
\hline $\mathrm{Nc}$ & $\frac{\mathrm{Sc}}{\mathrm{cal} / \mathrm{mole} / \mathrm{deg}}$ & Graphite & $\begin{array}{l}\text { Infinitely } \\
\text { dilute sol. }\end{array}$ & Graphite & Pure liquid \\
\hline $\begin{array}{l}0 \\
0.01 \\
0.02 \\
0.03 \\
0.04 \\
0.05 \\
0.06 \\
0.07 \\
0.08 \\
0.09 \\
0.10 \\
0.12 \\
0.14 \\
0.16 \\
0.18 \\
0.20 \\
0.211 *\end{array}$ & $\begin{array}{l}\infty \\
12 \cdot 3 \\
10 \cdot 6 \\
9 \cdot 5 \\
8 \cdot 7 \\
7 \cdot 9 \\
7 \cdot 3 \\
6 \cdot 7 \\
6 \cdot 1 \\
5 \cdot 6 \\
5 \cdot 1 \\
4 \cdot 3 \\
3 \cdot 7 \\
3 \cdot 1 \\
2 \cdot 8 \\
2 \cdot 4 \\
2 \cdot 25\end{array}$ & $\begin{array}{r}-0.260 \\
-0.196 \\
-0.132 \\
-0.068 \\
-0.009 \\
0.060 \\
0.124 \\
0.188 \\
0.252 \\
0.316 \\
0.380 \\
0.480 \\
0.541 \\
0.604 \\
0.631 \\
0.661 \\
0.677\end{array}$ & $\begin{array}{l}0 \\
0 \cdot 064 \\
0 \cdot 128 \\
0 \cdot 192 \\
0 \cdot 256 \\
0 \cdot 320 \\
0 \cdot 384 \\
0 \cdot 448 \\
0 \cdot 512 \\
0 \cdot 572 \\
0 \cdot 640 \\
0 \cdot 740 \\
0 \cdot 801 \\
0 \cdot 864 \\
0 \cdot 891 \\
0 \cdot 921 \\
0 \cdot 937\end{array}$ & $\begin{array}{l}0 \\
0 \cdot 0064 \\
0 \cdot 0148 \\
0 \cdot 0257 \\
0.0392 \\
0 \cdot 0574 \\
0 \cdot 0798 \\
0 \cdot 108 \\
0 \cdot 143 \\
0 \cdot 187 \\
0 \cdot 240 \\
0 \cdot 362 \\
0 \cdot 489 \\
0 \cdot 643 \\
0 \cdot 770 \\
0 \cdot 916 \\
1 \cdot 0\end{array}$ & $\begin{array}{l}1.0 \\
0.989 \\
0.977 \\
0.963 \\
0.948 \\
0.932 \\
0.914 \\
0.896 \\
0.875 \\
0.854 \\
0.831 \\
0 \cdot 789 \\
0.755 \\
0.718 \\
0.691 \\
0.663 \\
0.647\end{array}$ \\
\hline
\end{tabular}

* Melt saturated with graphite at $1560^{\circ} \mathrm{C}$. $\mathrm{H}_{\mathrm{c}}=4,130 \pm 1,000 \mathrm{cal} / \mathrm{mol}$.

$$
e_{\mathrm{O}}^{(\mathrm{C})}=\frac{\partial \log f_{\mathrm{o}}^{(\mathrm{C})}}{\partial \underline{\mathrm{C}} \%}=-0.421 \cdots(\text { very dil. }) \cdots
$$

また Wagner の式より酸素による炭素の活量变化は 次式のごとくである.

$$
e_{\mathrm{C}}^{(0)}=\frac{\partial \log f_{\mathrm{C}}^{(0)}}{\partial \underline{\mathrm{O}} \%}=-0 \cdot 316 \cdots(\text { very dil. }) \cdots
$$

3. $\underline{\mathrm{C}}+\underline{\mathrm{O}}=\mathrm{CO}$

$$
K_{3}=\mathrm{P}_{\mathrm{Co}} / a_{\mathrm{c}} \cdot a_{\mathrm{o}}
$$

熔鉄中の炭素と酸素の平衡は（1a)，(2a) 式を組合わ せることにより得られる.

$$
\begin{gathered}
\log K_{3}\left(=\frac{\mathrm{P}_{\mathrm{co}}}{a_{\mathrm{c}} \cdot a_{\mathrm{O}}}\right)=\frac{1,160}{\mathrm{~T}}+2 \cdot 00 \cdot \\
\Delta \mathrm{F}_{8}{ }^{0}=-5300-9.2 \mathrm{~T}
\end{gathered}
$$

(3)式の見掛け上の平衡恒数 $\log \mathrm{P}_{\mathrm{co}} / \underline{\mathrm{C}} \% .0$. $\%$ は, 実験結果によれば炭素濃度とともに減少する.すなわち 䖫鉄中の炭素と酸素の積 $\mathrm{C} \% \times \underline{0} \%=\mathrm{m}$, は炭素漉度と ともに増大し, その延長は炭素飽和における $\mathrm{Fe}-\mathrm{C}-\mathrm{O}$ 系平衡測定の著者などの値にほぼ一致する.

$\log K_{8}{ }^{\prime}$ からも前述と同様の方法により酸素の活量係 数におよほす炭素の影響を求め得る.

$$
\frac{\partial \log f_{\mathrm{o}}^{\mathrm{c}}}{\partial N_{\mathrm{C}}}=-9 \cdot 38 \cdots \cdots<0.09 N_{\mathrm{C}}
$$

$$
\begin{aligned}
& \frac{\partial \log f_{\mathrm{O}}^{(\mathrm{C})}}{\partial \underline{\mathrm{C}} \%}=-0.436 \cdots \cdots(\text { very dil. }) \\
& \frac{\partial \log f_{\mathrm{C}}^{(\mathrm{O})}}{\partial \underline{\mathrm{O}} \%}=-0.327 \cdots \cdots(\text { very dil. })
\end{aligned}
$$

以上を総合すれば, $\log K_{3}{ }^{\prime}$ は高炭素浱度では炭素の 影響が大きくなり，また低炭素濃度では酸素の影響が無 視できなくなり，つぎの近似式で示される.

$$
\begin{aligned}
& \log K_{3}{ }^{\prime}=\log K_{3}-2 \cdot 98 N_{\mathrm{C}} \\
& 0.005 \sim 0 \cdot 09 N_{\mathrm{C}}(0 \cdot 1 \sim 2 \cdot 5 \% \text { C) } \\
& \log K_{8}{ }^{\prime}=\log K_{3}-0.527 \mathrm{O} \% \\
& <0.005 N_{\mathrm{C}}(0.1 \% \mathrm{C})
\end{aligned}
$$$$
\text { 文献 }
$$

1）的場，万谷：鉄と鎆，43（1957）790 
（18）熔鉄の窒素溶解度におよぼす $\mathrm{Ni}, \mathrm{Co}, \mathrm{Mo}, \mathrm{Cr}, \mathrm{V}$ の影響

（熔鉄の窒素の溶解度についてーII）

日本製鋼所，室蘭製作所

理博 前川静弥・理博○中川義隆・梁川保雄

Effect of $\mathrm{Ni}, \mathrm{Co}, \mathrm{Mo}, \mathrm{Cr}$ and $\mathrm{V}$ on the Solubility of Nitrogen in Liquid Iron.

(Solubility of nitrogen in liquid iron and iron alloys $-\mathbb{I}$ )

Shizuya Maekawa, Yoshitaka Nakagawa and Yasuo Yanagawa.

\section{I. 緒}

\section{言}

第 1 報の熔融純鉄, 鉄一珪素系, 鉄一マンガン系1に 引続き鉄一ニッヶル系, 鉄一コバルト系, 鉄一モリブデ ン采, 鉄一クロム系㧍よび鉄一バナジウム系, 熔融鉄合 金の窒素溶解度の測定結果について報告する.

\section{II. 実 験 方 法}

\section{1. 要旨}

$\mathrm{Fe}-\mathrm{Ni}, \mathrm{Fe}-\mathrm{Co}, \mathrm{Fe}-\mathrm{Mo}, \mathrm{Fe}-\mathrm{Cr}$ および $\mathrm{Fe}-\mathrm{V}$ 系の熔融 合金に一気圧の $\mathrm{N}_{2}$ ガスを接触せしめ, 一定時間ごとに 試料を採取し， $\mathrm{N}$ 量を定量して $\mathrm{N}$ 飽和溶解量を求めた。

2. 実験装置

実験装置は前報と全く同様で $\mathrm{N}_{2}, \mathrm{H}_{2}$ および $\mathrm{Ar} カ ゙$ スの洗浄装置および反応管よりなつている. ガスの洗浄 系列の細部は Fig. 1 に示すごとくで，とくにガス中の $\mathrm{O}_{2}$ の除去に注意した.

反応管は, 高アルミナ質坩堝によつて保護した電融ア ルミナ質坩堝（内径 $30 \mathrm{~mm}$, 高さ $50 \mathrm{~mm}$ ) を石英管中 におさめこの中の試料を高周波電気炉（水銀ギャップ式

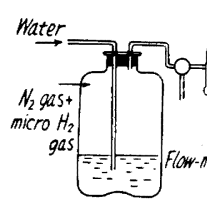

Gas-Tank

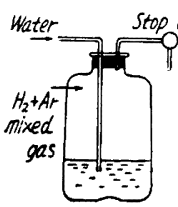

Gas-Tank
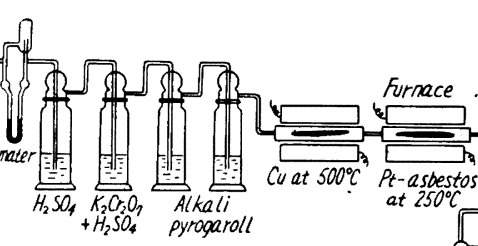

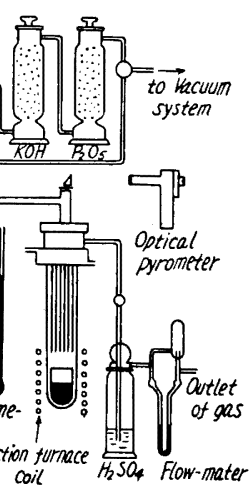

coil
$10 \mathrm{KVA}$ )で焀解した. 分析試料の採取方法は前報と全 く同様である.

\section{3. 供試料}

実験に用いた純鉄は一旦真空熔解灯で $5 \mathrm{~kg}$ の電解鉄 を熔解して小鋼塊とし、これを実験用坩堝に適合するよ う成形したものを用いた．その化学組成はつぎのごとく である。

Chemical composition of vacuum-melted electrolytic iron.

\begin{tabular}{c|c|c|c|c|c}
\hline $\begin{array}{l}\text { Compo- } \\
\text { sition }\end{array}$ & $\mathrm{C}$ & $\mathrm{Si}$ & $\mathrm{Mn}$ & $\mathrm{O}$ & $\mathrm{N}$ \\
\hline$\%$ & $<0.006$ & $<0.005$ & $<0.005$ & $<0.01$ & $<0.003$ \\
\hline
\end{tabular}

また各種添加金属の純度を次表に示す。

Purity of alloying element.

\begin{tabular}{cc|c|c|c|c}
\hline $\begin{array}{c}\text { Alloying } \\
\text { element }\end{array}$ & $\mathrm{Ni}$ & Co & Mo & Cr & $\mathrm{V}$ \\
\hline$\%$ & $99 \cdot 28$ & 99.57 & 99.93 & 99.0 & 99.78 \\
\hline
\end{tabular}

4. 温度測定

吸収量測定時と全く同じ状態で, $\mathrm{Pt}-\mathrm{Pt} \cdot \mathrm{Rh}$ 熱電対 （純 $\mathrm{Ni}$ の焀融点で補正）と光高温計との同時測定を行 なつて光高温計を補正し実験中は光高温計によつて温度 測定を行なつた。

\section{5. 実験順序}

試料約 $125 \mathrm{~kg}$ を反応管内の坩堝におさめ装置内を $\mathrm{H}_{2}$ -Ar 混合ガス（1：1）にて完全に置換したる後, 高周 波電気炉を作動し試料熔解後混合ガスを $100 \mathrm{cc} / \mathrm{mn}$ の割 合で通じながら約 40 分間 $1600^{\circ} \mathrm{C}$ に保持する. 次で反 応管内を一旦真空とした後, $\mathrm{N}_{2}$ ガスに切換え, $150 \mathrm{cc} /$ $\mathrm{mn}$ の割合で通しながら所定温度に保持する. その後10 〜20分ごとに分析試料を $2 \sim 5 \mathrm{~g}$ 採 取する.採取試料は直ちに水冷して 分析に供する.

\section{6. 分析方法}

試料のN分析はアンモニア蒸溜一 中和滴定法, また $\mathrm{Ni}, \mathrm{Co}, \mathrm{Mo}, \mathrm{Cr}$ およびVの分析は学振鉄鋼迅速分析 法によつて行なつた。

7. その他

Nの活量倸数 $f_{\mathrm{N}}^{(\mathrm{X})} ;$ および相互 作用助係数 $e_{\mathrm{N}}^{(\mathrm{X})}$ は前報と同じ要領 で求めた。

Fig. 1. Appartus used in experiments. 
III. 実 験 結 果

$\mathrm{Fe}-\mathrm{Ni}, \mathrm{Fe}-\mathrm{Co}$, $\mathrm{Fe}-\mathrm{Mo}, \mathrm{Fe}-\mathrm{Cr}$ お よび $\mathrm{Fe}-\mathrm{V}$ 系溶 鉄のNの飽和溶解 量を Fig. 2 に示 した.

すなわち各系溶 鉄とも温度の差異 によるNの溶解度 の変化は明暸でな かつたが，これら の結果によると溶 鉄中の $\mathrm{Ni}, \mathrm{Co}$, はNの溶解度を減 少し，また Mo，

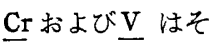
の順序にしたがつ てNの溶解度を增 加する.

また Fig. 2 の 関保より共存元素 $\mathrm{X}$ の重量\%と $\log$ $f_{\mathrm{N}}^{(\mathrm{X})}$ との関係を 求め, これを示す と Fig. 3 に示す ごとくになる.

Fig. 3 の関係よ

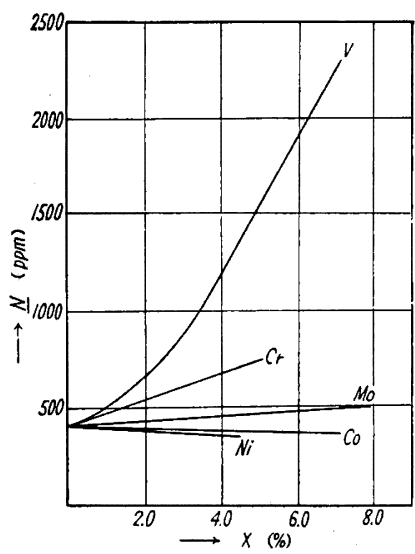

Fig. 2. Effect of various elements on the solubility of nitrogen in liquid iron.

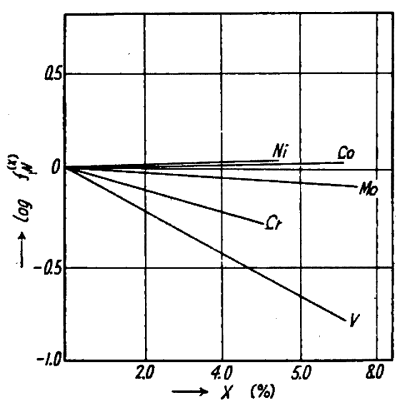

Fig. 3. Effect of various elements on the activity coeffi. cient of nitrogen. n

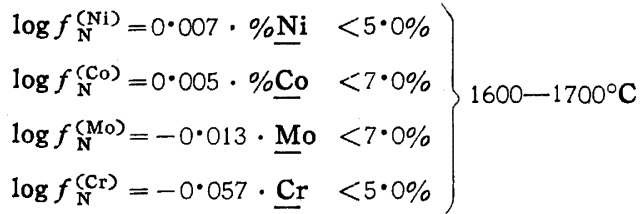

$$
\begin{aligned}
& \log f_{\mathrm{N}}^{(\mathrm{V})}=-0.11 \cdot \% \underline{\mathrm{V}}<8.0 \% \quad 1600-1750^{\circ} \mathrm{C} \\
& \text { なる関係式が得られる。 }
\end{aligned}
$$

$$
\text { IV. 結 言 }
$$

以上溶鉄の $\mathrm{N}$ 飽和溶解度におよぼす $\mathrm{Ni}, \mathrm{Co}, \mathrm{Mo}, \mathrm{Cr}$ およびVの影響について実験したが $\mathrm{Fe}-\mathrm{Ni}$ 系溶鉄にお いては,

Langenberg ${ }^{2)}$, Kashyap \& Parlee ${ }^{3)}$, Wentrap \&

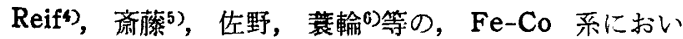
ては Schenck 等》, Fe-Mo 系では Kashyap \& Parlee ${ }^{2)}$, Shenck 等 ${ }^{7}, \mathrm{Fe}-\mathrm{Cr}$ 系( (斎藤 $^{5}$, 的場・不破 ${ }^{8}$

$\mathrm{Fe}-\mathrm{V}$ 系では佐野, 萇輪6), Kashyap \& Parlee ${ }^{3)}$ 等の 実験結果や調査結果が発表されている.

これらの結果よりの合金元素1\%に扮けるNに対する 相互作用助倸数 $e_{\mathrm{N}}^{(\mathrm{X})}$ は $\mathrm{Fe}-\mathrm{Ni}$ 系: 0.002 0.009, Fe -Co 系: 0.0072, Fe-Mo 采: 0.0043 0.0098, $\mathrm{Fe}-\mathrm{Cr}$ 系: -0.045 0.06, $\mathrm{Fe}-\mathrm{V}$ 系: -0.095〜ー0.19 であ る.

これに対し本実呀結果より求めた $e_{\mathrm{N}}^{(\mathrm{X})}$ はそれぞれ $0.007,0.005,-0.013,-0.057,-0.11$ であり, お おむねよい一致を示した。

\section{交献}

1) 前川静弥, 中川義隆：鉄と鋼，45（1959） 255

2) F. Langenberg: J. Metals 8 (1956) 1099

3) V. C. Kashyap \& N. Parlee: Trans. Metallurgcal Soc. A.I.M.E., 212 (1958) 86

4) H. Wentrap \& O. Reif: Archiv Eisenhütt., 20 (1949) 359

5 ) 斎藤恒三: 金属学会誌B-14（1950） 1

6 ）佐野幸吉・諘輸晋：金属学会誌，21（1957）569

7) H. Schenck K.M.G. Frohberg \& H. Graf: Archiv Eisenhütt., 29 (1958) 673

8 ）的場幸雄，不破 祐：学振 19 委 5593 (1959)

\section{(19)}

\section{熔鉄の窒素溶解度におよぼす} Ti, Al, および O の影響

（熔鉄の窒素の溶解度について一III）

日本製鋼所，室蘭製作所

理博 前川静弥・博理O中川義隆・梁川保雄 Effect of $\mathrm{Ti}, \mathrm{Al}$ and $\mathrm{O}$ on the Solubility of Nitrogen in Liquid Iron.

(Solubility of nitrogen in liquid iron and iron alloys- $-\mathbb{I}$ )

Shizuya Maekawa, Yoshitaka Nakagawa and Yasuo Yanagawa.

\section{I. 緒}

\section{高}

前報に引続き溶鉄の窒素の溶解度におよぼす $\mathrm{Ti}, \mathrm{Al}$ およびOの影響について実験した結果と,第 3 元素の影 響に関する二，三の考察を取䌒めて報告する。

\section{II. $\mathrm{Fe}-\mathrm{Ti}, \mathrm{Fe}-\mathrm{Al}, \mathrm{Fe}-\mathrm{O}$ 系溶鉄のN溶解度}

実験方法は前報と全く同様である。 $\mathrm{Fe}-\mathrm{Ti}$ 系溶鉄は スポンヂチタン (99.5\%) を， Fe- $\mathrm{Al}$ 系溶鉄では金属 Al (99・0\%) をまた $\mathrm{Fe}-\mathrm{O}$ 系溶鉄では， $\mathrm{Fe}_{2} \mathrm{O}_{3}$ （化 学用）をとれぞれ用いた。

$\mathrm{Fe}-\mathrm{Ti}$ 系溶鉄においては $\mathrm{Ti}$ の蒸発が顕著であり, 
その含有量の規正が非常に困難である.その上溶湯中に Ti の窒化物が浮遊し溶鉄と二層になつて存在する.

また $\mathrm{Fe}-\mathrm{Al}$ 系は, $\mathrm{Fe}-\mathrm{Ti}$ 系溶鉄と同梯に窒化物が 浮遊し坩堝の壁付近に溶鉄とは別の層をなして存在す る.このため実験が困難でとくに低温においてはこの二 層の分離が充分に行なわれず，試料採取が不可能であつ た。このような理由により $\mathrm{Fe}-\mathrm{Ti}$ および $\mathrm{Fe}-\mathrm{Al}$ 系の 実験温度はいずれも $1700^{\circ} \mathrm{C}$ とした。

さらに Fe-O 系はまずアルゴン気流中で電解鉄を溶 解し $\mathrm{Fe}_{2} \mathrm{O}_{3}$ を適宜変化せしめて添加し, 溶解母材を作 り，これを実験坩堝に適合するごとく成形して，坩堝に おさめ実験装置内にて溶解し，これに $\mathrm{H}_{2}$ ガスを 0 60 分間適宜時間を变えて通じた.

しかる後，一旦真空としてから $\mathrm{N}_{2}$ ガスを通じた。こ の操作により溶鉄中の量を変化せしめんとしたが，そ の調節が困難でO量は約 $0.15 \%$ 以上，および $0.01 〜 ~$ 0・04\%\%の濃度範囲のものは得られなかつた.

\section{III. 実 験 結 果}

$\mathrm{Fe}-\mathrm{Ti}, \mathrm{Fe}-\mathrm{Al}$ お よび $\mathrm{Fe}-\mathrm{O}$ 系溶鉄 のNの飽和溶解量を

Fig. 1 に示した.

これらの溶鉄は, 前報に報告せる C， $\mathrm{Si}, \mathrm{Mn}, \mathrm{Ni}, \mathrm{Co}$, Mo， CrおよびVの 各系より実験が非常 に困難であつて，今 後さらに実験を重ね 正確を期することが 必要である.すなわ ち, $\mathrm{Ti}, \mathrm{Al}$ の場合 は窒化物と推定され るものが，溶湯の表 面に生ずるこ上，ま た蒸発などによつて 所定の含有量のコン
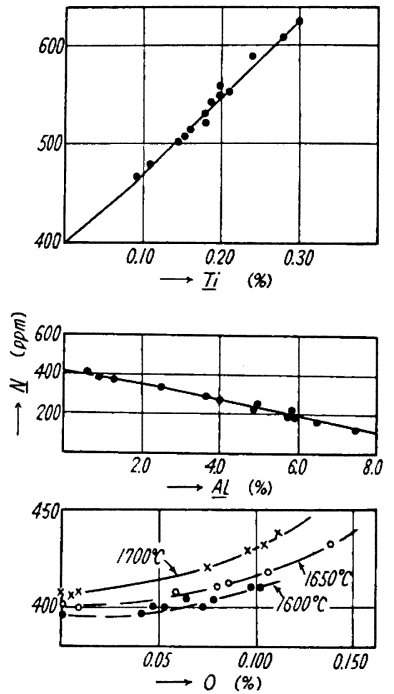

Fig. 1. Effect of Ti, Al, and $O$ on the solubility of nitrogen in liquid iron.

トロールが期待通りできないことなどの問題がある。こ れらの点については, さらに今後究明する予定であるが 以上の結果より $\log f_{\mathrm{N}}^{(\mathrm{X})}$ を冰めると次式のごとくなる.

$\mathrm{Fe}-\mathrm{Ti}$ 系溶鉄では

$\log f_{\mathrm{N}}^{(\mathrm{Ti})}=-0.63 \%$ Ti $\left(\mathrm{Ti}<0.3 \%, 1700^{\circ} \mathrm{C}\right)$

$\mathrm{Fe}-\mathrm{A} 1$ 系溶鉄では

$\log f_{\mathrm{N}}^{(\mathrm{A} 1)}=0 \cdot 009 \cdot(\% \underline{\mathrm{A} 1})^{2}+0 \cdot 008 \cdot(\% \underline{\mathrm{Al}})-0.011$
$\left(\mathrm{Al}<8 \cdot 0 \%, 1700^{\circ} \mathrm{C}\right)$

また $\mathrm{Fe}-\mathrm{O}$ 系溶鉄では

$\log f_{\mathrm{N}}^{(\mathrm{O})}=-0.19 . \% \mathrm{O}(\mathrm{O}, 0.05 \sim 0.14 \%, 1600 \sim$ $\left.1700^{\circ} \mathrm{C}\right)$

なる結果を得た。

IV. 結言ならびに各種元素が溶鉄の $\underline{N}$ 溶解度におよほす影響の考察

筆者らは実際現場作業に直接必要である C, $\mathrm{Si}, \mathrm{Mn}$, $\mathrm{Ni}, \mathrm{Co}, \mathrm{Mo}, \mathrm{Cr}, \mathrm{V}, \mathrm{Ti}, \mathrm{Al}$ および O が溶鉄のN溶解 度におよぼす影響について実測し，これらの元素の溶鉄 中のNに対する相互作用助係数 $e_{\mathrm{N}}^{(\mathrm{X})}$ を求めた.

その結果を一括して示すと本研究の温 度範囲では Table 1 のごとくである.

Table 1. Values of parameters $e_{\mathrm{N}}(\mathrm{X})=\log f_{\mathrm{N}}(\mathrm{X})$ at $1 \% \mathrm{X}$.

\begin{tabular}{c|c|c|c|c|c}
\hline $\mathrm{X}$ & $\mathrm{C}$ & $\mathrm{Si}$ & $\mathrm{Mn}$ & $\mathrm{Ni}$ & $\mathrm{co}$ \\
\hline$e_{\mathrm{N}} \mathrm{(x)}$ & 0.135 & 0.048 & -0.020 & 0.007 & 0.005 \\
\hline \hline $\mathrm{Mo}$ & $\mathrm{Cr}$ & $\mathrm{V}$ & $\mathrm{Ti}$ & $\mathrm{Al}$ & 0 \\
\hline-0.013 & -0.057 & -0.11 & $(-0.63)$ & 0.006 & $(-0.19)$ \\
\hline
\end{tabular}

すなわち， Nの活動度は Mo, Mn, Cr, V, O, Ti の順 に減少し, また $\mathrm{Co}, \mathrm{Ni}, \mathrm{Al}, \mathrm{Si}, \mathrm{C}$ の順に增大する.

また各種合金元素の原子番号と $e \underset{\mathrm{N}}{(\mathrm{X})}$ との関係を示す と Fig. 2 のごとくである.

すなわち，きわめて明嘹な規則性を示し，第 3 週期の 元素群と第 4 週期の元素群は明らかに分れていて, 原子 番号の增大による $e \underset{N}{(\mathrm{X})}$ の増減の傾向がよく類似してい

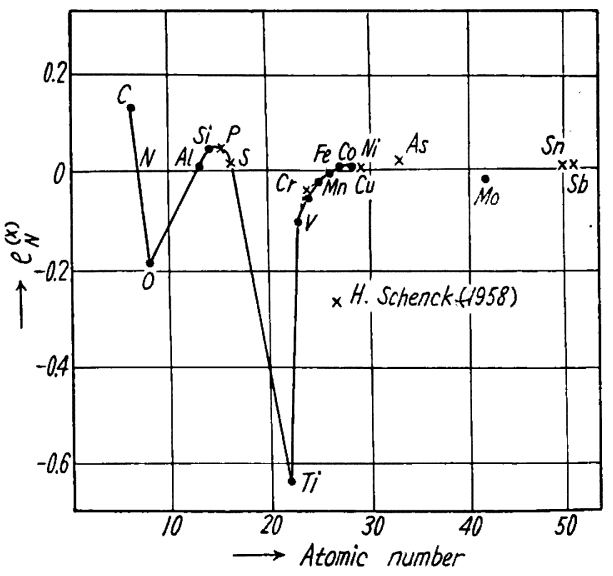

Fig. 2. Relation between atomic number and $e_{\mathrm{N}}^{(\mathrm{X})}$. 
る.

これらの内 Si と吕に関しては, 従来の報告と全く逆 の結果を示している. Si に関しては最近 M.I. T. の Chipman のもとで, R. D. Pehlke が筆者と同じょう な傾向の結果を得ているとのことである.

現在, データを交換中であるので，後日よく検討する 積りである.ささらにOに関しては, Schenck ${ }^{1}$ の值

$$
e_{\mathrm{N}}^{(\mathrm{O})}=1 \cdot \mathrm{CO}
$$

と㹥全く異なるが，

三本木, 大谷両氏2) は $e_{0}^{(\mathrm{N})}$ について $e_{\mathrm{O}}^{(\mathrm{X})}$ と各種添 加元素の原子番号との規則性より

$$
e_{0}^{(N)}=-0 \cdot 13
$$

なる値を推定している.したがつて，

$$
e_{\mathrm{N}}^{(0)}=e_{\mathrm{O}}^{(\mathrm{N})} \times \frac{14}{16}=-0.11
$$

を推定し得る.

$$
\text { この值前揭の } e_{\mathrm{N}}^{(0)}=-0 \cdot 16 \quad\left(1600 \sim 1650^{\circ} \mathrm{C}\right)
$$

とはかなりよい一致を示している.

しかし， $\mathrm{Fe}-\mathrm{O}$ 系溶鉄は実験上に多くの困難があるの で今後さらに検討する必要があろう。

他の元素についてはおおむ放満足し得る結果である 占，蒸発し易い元素を含む系についても， $\mathrm{Fe}-\mathrm{O}$ 系溶鉄 と同じく,より正確を期して実験を行なうことが望まし w.

\section{交献}

1) H. Schenck K.M.G. Frohberg \& H. Graf: Archiv Eisenhüttw., 29 (1958) 673

2) 三本木貢治，大谷正康：学振資料，19委5426 (1959)

（20）焼結原料における返釷量について 住友金属工業，小合製鉄所

実松 竹二・O豊沢 弘喜

On the Quantity of Return Fines in the Sinter Mixture.

Takezi Sanematsu and Hiroki Toyozawa.

\section{I. 緒言}

近時，焼結鉱の高炉装入物としての洒值が認められ， 焼結鉱の増産が強く要望されつつあるが，その対策の一 つとして返鉱の発生量を減少せしめて成品歩留を向上さ せることが考えられる.

しかしながら害際作業上の返鉱は二つの構成要素から 成り，（1）焼結過程において塊状化されたものが破哗過
程において粉砕して篩下（返鉱）となるもの，（2）装入 密度の不均一および粒度成分の偏析などにより烧結進行 状態が不均一となり焼結反応を起さずほとんど原料のま ま未焼結部分となつて返鉱に入るものとがある。しかし て（2）㥛力これを減少せしめる必要のあることは論 をまたない（1）は単なる発生粉という意味のほかに 配合原料粒度の改善によつて焼結進行中に酸化物を結合 して融点を下げ焼結化合物の生成を助けて生産性を向上 せしめるという大きな意義が強調されている。

寸なわち本実験においてはかかる意味を有する返鉱の 適正量について論ずるものである．与えられた原料に対 して返鉱量が少ない々一時的には成品歩留は向上与るが 配合原料の通風性泜下し，焼結時間が長くなり生産量 が減少するとともに品質も悪くなる，逆に返鉱が多きに すぎると焼結速度は増すが一方成品歩留は低下すること が考えられる.したがつて現在の配合における生産量, 品質ともに満足せしめうるような返鉱の適正量はいか程 であるかが問題となる．そこでこれらの関係を量的に把 握して当所自溶性焼結鉱配合において生産量が最大とな り，かつ品質的にも最も良好となるような適正返鉱量を 見出すべくこれに関する一連の試験を行なつた。

\section{II. 試 験 方 法}

試験鍋を使用し Table 1，2 亿示与成分，粒度の原 料を使用して Table 3 に示与配合割合にて試験を行な

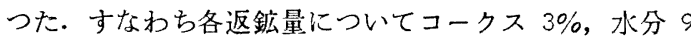
$\% ， 10 \% ， 11 \%$ として生産係数の最大となる水分值を見 い出し，その水分でコークス配合量 2.5\%，3.5\%の試 験を行ない，各返鉱量における水分，コークス量の影響 および返鉱量の焼結条件，成品品質，生産量などにおよ

Table 1. Chemical analysis of raw materials.

\begin{tabular}{l|r|r|c}
\hline \hline & T. Fe & FeO & S \\
\hline Pyrite cinder & $58 \cdot 67$ & $5 \cdot 17$ & $1 \cdot 695$ \\
Fine pyrite cinder & $56 \cdot 26$ & $6 \cdot 20$ & $2 \cdot 080$ \\
S. F. Larap & $53 \cdot 04$ & $23 \cdot 43$ & $3 \cdot 611$ \\
Mill scale & $69 \cdot 92$ & $54 \cdot 64$ & $0 \cdot 377$ \\
Iron sand & $61 \cdot 88$ & $27 \cdot 22$ & $0 \cdot 135$ \\
Flue dust & $44 \cdot 71$ & $43 \cdot 40$ & $0 \cdot 352$ \\
Return fines & $54 \cdot 65$ & $16 \cdot 19$ & $0 \cdot 338$ \\
\hline
\end{tabular}

Table 3 .

\begin{tabular}{c|c|c|c|c}
\hline $\begin{array}{c}\text { Pyrite } \\
\text { cinder }\end{array}$ & $\begin{array}{c}\text { Fine pyrite } \\
\text { cinder }\end{array}$ & S. F. Larap & Mill scale \\
\hline 30 & 10 & \multicolumn{2}{|c|}{27} & 10 \\
\hline \hline $\begin{array}{c}\text { Iron } \\
\text { sand }\end{array}$ & $\begin{array}{c}\text { Flue } \\
\text { dust }\end{array}$ & $\begin{array}{c}\text { Lime } \\
\text { stone }\end{array}$ & $\begin{array}{c}\text { Return } \\
\text { fines }\end{array}$ & Coke \\
\cline { 2 - 5 } 6 & 4 & 13 & $\begin{array}{c}10 \cdot 20 \\
30 \cdot 40\end{array}$ & $\begin{array}{c}2 \cdot 53 \cdot 0 \\
3 \cdot 5\end{array}$ \\
\hline
\end{tabular}

